\title{
The influence of ICT instruments on a transmission of interest rates by business entities and public authorities - A scientific comment

\author{
Bartlomiej Hadasik
}

Department of Business Informatics, University of Economics in Katowice, ul. 1 Maja 50, 40-287 Katowice, Poland. Email: bartlomiej.hadasik@edu.uekat.pl

\section{Keywords}

Interest Rates, ICT, Information and Communication Technology, Market Efficiency, Transmission of Information.

Article History

Received on $27^{\text {th }}$ October 2021

Accepted on $15^{\text {th }}$ January 2022

Published on $27^{\text {th }}$ January 2022

Cite this article

Hadasik, B. (2022). The influence of ICT instruments on a transmission of interest rates by business entities and public authorities - A scientific comment. Humanities \& Social Sciences Reviews, $10(1), 17-23$

https://doi.org/10.18510/hssr.2022.1013

Copyright @ Author

Publishing License

This work is licensed under a Creative Commons Attribution-Share Alike 4.0 International License

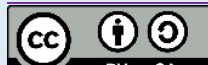

\section{Abstract}

Purpose of the study: This article aims to present the role played by electronic communication tools from the economic and investor perspective. The paper focuses on three axes: ICT for a transmission of information on interest rates, ICT as a source of information for investors and ICT for improving market efficiency.

Methodology: The article is exploratory in nature, which means that in order to investigate the individual pillars of this work, an analysis of the corresponding literature sources has been made. An extensive review of scientific articles, scientific books, and working papers corresponding to individual axes was made.

Main Findings: ICT tools show an advantage over other (more traditional) communication channels, which is reflected in more dynamic and immediate market reactions. High use of these tools is observed both among enterprises and central agencies. The effective transmission of information about interest rates minimizes the risk of making wrong investment decisions. However, it is important to bear in mind the challenges of, inter alia, still low level of digital literacy among the society.

Applications of the study: This work may be an incentive for entrepreneurs to digitize their companies more widely, but also for investors to use ICT to make investment decisions more accurately.

Novelty/Originality of the study: The paper presents a broad literature overview on using ICT tools in economic applications, including investment. The starting point is also behavioral decision-making theories along with classical heuristics.

\section{INTRODUCTION}

Modern communication tools (in particular with the use of modern technologies) allow for a quick flow of information, which translates into more dynamic reactions (Bañares \& Altmann, 2018). Compared to traditional media (such as paper newspapers), communication via the Internet is rapid, making instant decision-making easier. This has many consequences - in terms of economics, it may be the optimization of the basket of goods, while in terms of finance, it may increase the efficiency of financial markets. Both consumers and investors, through targeted information on e.g.,

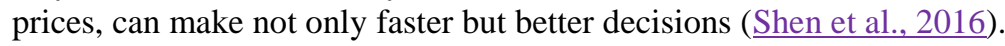

The issue of trust in the quality of communication and individual sources of communication (differences between messages on industry portals and entries on social networks), as well as the possibility of such messages translating into investor and consumer behavior, should also be taken into account. As early as 1979, attention was drawn to the impact of information about the price of a given good on consumer behavior (Devine \& Marion, 1979). However, over the years, many authors emphasize the importance of collecting various information by consumers as the basis for making rational decisions, not so much as those consistent with their preferences (Sowa, 1997; Crotts, 1999; Smyczek, 2000; Falkowski \& Tyszka, 2009).

The importance of the influence of emotional charge on decisions was the basis for building a behavioral theory. Based on people's perceptions of different stimuli and decision-making patterns of others, Kahneman and Tversky (1979) developed a perspective theory, taking into account heuristics (Tversky \& Kahneman, 1974; Kahneman et al., 1982) and then extending their concept (Kahneman \& Tversky, 1979, 1984). According to Zatwarnicka-Madura (2009, p. 19), "consumer behavior is not always the result of deliberate acts of choice, but often reactions (often unconscious and rejected) to external stimuli or specific situations." Therefore, the information itself is crucial. Relating this to the field of finance, still following the behavioral trend, De Bondt and Thaler (1985) showed that investors reacted more than it should be when making rational decisions. It should be emphasized that the full value of investment decisions made (with the participation of behavioral heuristics) will be achieved by eliminating potential cognitive biases (Otuteye \& Siddiquee, 2015).

Proper communication and shaping market expectations is also a pivotal instrument of monetary policy (SkibińskaFabrowska, 2015). Thanks to information and communication technologies (ICT) tools, press conferences can be broadcast on the web, and anyone with Internet access and a connection device can watch them. ${ }^{1}$ Thus, access to the inf-

${ }^{1} \mathrm{~A}$ necessary condition for the forward guidance policy to be effective is not only to shape expectations but also to make decisions that are consistent with the adopted strategy, e.g., of direct inflation targeting. 
-ormation is unlimited and a transmission of interest rate changes can be instantly discounted in share prices.

This scientific comment focuses on three axes:

1. The role of ICT in more effective transmission of interest rates;

2. Internet ICT tools as a source of information for investors;

3. ICT as an instrument for improving market efficiency.

\section{THE ROLE OF ICT IN MORE EFFECTIVE TRANSMISSION OF INTEREST RATES}

The basic instruments of monetary policy are those having an indirect effect, such as: the policy of required reserves, refinancing loans, the open market policy (Kaźmierczak, 2000, p. 101) and those having a direct impact: controlling the value of loans granted to customers and controlling the level of interest rates (Kaźmierczak, 2000, p. 114). Monetary policy instruments are complex and can be used simultaneously, however, to enhance their impact, and even to influence the market without using them, a policy of shaping market expectations is used.

Communicating with stakeholders is the basis for running modern central banks under the forward guidance policy. Although initially it was a considerable support for the implementation of the direct inflation targeting (DIT) strategy, it is now a significant instrument of monetary policy (Skibińska-Fabrowska, 2015). The role of the central bank's communication with the environment was particularly noticed when the classic instruments of monetary policy were exhausted. According to Grądalski and Guzikowska (2015), the forward guidance policy is described as " $a$ return to a credible promise will become an effective instrument of monetary policy in conditions of zero interest rates and will allow to solve the problem of policy inconsistency over time."

Informing about decisions on future interest rate levels as an element of the monetary policy of central banks is of a paramount importance in the context of global crises. Proper communication enables the appropriate application of macroprudential mechanisms in financial policy, inter alia, to limit the negative economic effects of the coronavirus pandemic (Petryka, 2021). According to Kubiczek (2020a), forward guidance in the issue of the European Central Bank brought outstandingly good results during the first wave of the COVID-19 pandemic, as a result of which there was no need to cut interest rates below zero. These interest rates are communicated by the central banks of individual countries, including international organizations such as the European Union in the case of a particular circumstance such as the European Central Bank. Interest rates on inflation, unemployment or other statistical data influencing the functioning of public life are, in turn, communicated by public statistics bodies, such as the Central Statistical Office (Kubiczek, 2020a).

The abovementioned central authorities use technological portfolios to communicate about rates, indices or other indicators of economic development. They allow for adequate and quick transmission of messages to any place globally with an Internet connection. In addition, using ICT appliances in organizations allows avoiding additional costs, as a transmission of messages does not require extra expenses for campaigns in traditional media. The use of instruments for communicating via the Internet also allows for effective targeting of information recipients (also in the case of public applications), which is difficult in the issue of using traditional marketing tools. As a result, information reaches only interested groups without incurring additional expenditures (Hazenberg et al., 2018).

Due to the abovementioned merits of electronic communication tools and thus their advantages over messages in traditional media, it is noted that the contribution of ICT utilization to economic growth is robust; however, implementation of ICT instruments to central agendas depends on governmental policy (Vu, 2013; Shahiduzzaman \& Alam, 2014). Many emerging countries are striving hard to incorporate ICT while harmonizing their limited income allocation in order to catch up quickly with developed economies (Shirazi et al., 2009; Bankole et al., 2015). The high use of ICT tools is considered an important indicator of the economic development of the region (Kubiczek \& Bieleń, 2021). It is also vital to point out that in order to take full advantage of the ICT tools' virtues, it is important to have broadband Internet access both on the side of the issuer of the message and the recipient. Access to broadband Internet has significantly influenced the economic development of countries, employment and national competitiveness (Czernich et al., 2011; Ng et al., 2013; Vu, 2013).

Conducting the information policy in a transparent manner and its consistent implementation gives reliability to the monetary policy and stabilizes inflation expectations (Grądalski \& Guzikowska, 2015). Transparency and credibility are the basis for investors as the primary risk control (Maynard, 2018), hence the application of an open communication policy with using information tools. Currently, ICT is an indispensable element not only of business activity of enterprises, but also of economic policy. State sector bodies, by using electronic communication tools, perform their public roles more effectively, being more open to the needs of the information society.

\section{ICT AS THE SOURCE OF INFORMATION FOR INVESTORS}

Investors, striving to make a decision about choosing the optimal investment portfolio, take into account many different sources of information, including those relating to interest rates communicated by central banks, as well as economic development indicators reported by public statistics authorities (Zaremba, 2015). They are usually published on the official websites of central agencies (as part of public information bulletins); however, it is increasingly noticed that 
short information promulgations are also published on official profiles on social networks of these central authorities, as well as in press articles in recognized trade magazines with reference to the official announcement.

When the Internet was not widespread, investors and people interested in the financial industry, wanting to learn about news from the industry world, read paper versions of recognized financial periodicals such as "The Financial Times" or "The Wall Street Journal," where the most important information, articles, recommendations from the economic and financial sector are being found. Based on these reports, the financiers made decisions that they implemented when the world stock markets were opened the next day, regardless of their opening hours, which differ depending on the time zone of the country in which they are located. The fundamental disadvantages of this communication channel are the relatively high costs of providing information and the long time counted from obtaining information to making a decision by the investor. Namely, having obtained the information, it must be edited, authorized, and published in a newspaper, which undergoes an expensive distribution process. The whole process is enriched with wide time frames and therefore the market reaction is postponed. The costs of providing such information are also relatively high: publication in a reputable/prestigious trade journal can cost significantly, as is the case with radio or TV advertising.

Nowadays, in the age of ubiquitous social media and mobile devices, information is obtained on a real-time basis, also in the instance of news from the financial world, which results in an almost immediate market reaction. The use of the Internet to inform investors or the broadly understood market is present not only among central public agencies, including central banks or public statistics bodies, to communicate the broadly understood financial situation of a given country. They are also - almost cost-free - used not only by investors but also private entrepreneurs, press spokesmen for stock exchange indices, but also economic journalists from industry media (such as "The Wall Street Journal," "The Financial Times" or "Bloomberg"). Notifications to financial information from RSS feeds or currently more popular accounts from Twitter or Facebook can be distributed in just a few seconds to devices used by investors. It is noted that digital communication and information instruments are currently one of the core of capital markets ( $\underline{\text { Kubiczek, 2020b) }}$.

Investors use the Internet as a fast and cheap source of information transmission, thanks to which it is possible to optimize decisions made more effectively. The decision-making process itself is also enhanced thanks to the fast procedure of information transmission on the Internet. First of all: to make stock exchange and currency investments, the current rates should be analyzed, followed by the check of their relations to historical rates. Among the ICT tools, there are many websites as well as mobile applications that allow you to check rates and indicators in an interactive and realtime way. These include: Bloomberg's investment and information tools (such as Bloomberg Terminal, Markets, Stocks, Currencies), Stooq.pl, Google Finance and Yahoo Finance. These are commercial aggregates of the most important indicators and indices (like those connected with stock exchange fluctuations, currency, etc.), which accumulate the most important financial information regarding particulars that are salient for the investor directly on the interactive dashboard of the application. Investors, however, also obtain the necessary information directly from the source, that is, inter alia, from the websites of central banks, stock exchange indices, as well as public statistics authorities. Apart from financial information for investors, inflation rates or indices of economic development of the country are also principal, which are communicated directly by official statistics agencies. Investment decisions are also influenced by ratings made by major rating agencies, which determine the degree of risk of investment success, which is an important factor for an investor (Altman \& Rijken, 2004).

Dynamic market reactions, triggered by the speed of transfer and access to qualitative information, help investors achieve better rates of return, and also limit the possibility of making a wrong investment due to more up-to-date information (Grinold \& Kahn, 2000; Adamska \& Dabrowski, 2016). Moreover, the timeliness of messages delivered with the use of ICT tools allows achieving an advantage based on information asymmetry over other investors, which translates into greater effectiveness of decisions made. Thus, it is possible to achieve greater profits from the investments made or minimize losses.

To make the right investment decisions, investors strive to have the most up-to-date information on interest rates (reference, inflation, interbank offer rates, etc.), which directly translates into the servicing of deposits and loans (Liberda et al., 2002). Moreover, in order to make an optimal investment, investors are also guided by the financial results of enterprises and investment funds, but also by the financial situation of the country where they are investing. Messages are often issued by entrepreneurs themselves or by managers of investment funds to maintain transparency and credibility (Nagy \& Obenberger, 1994). For the investor, messages from rating agencies (especially the largest and most respected ones, i.e., Fitch, Standard \& Poor's and Moody's; Richardson \& White, 2009, p. 101) are also of high importance, which, based on many factors, assess the credit (solvency) risk for a given entity (state or private) where the investment is made (White, 2013; Cole \& Cooley, 2014).

The use of ICT tools to make efficient investment decisions also presents a number of challenges. First of all, as the possessed information stimulates stakeholders to make a specific decision, the quality of such information should also be taken care of (Chengalur-Smith et al., 1999; Raghunathan, 1999). Stakeholders should carefully select sources of information in order to avoid the fact that unverified information (or even false information - the so-called fake news) will be a determinant of making an unfavorable decision. Currently, there is the phenomenon of infodemic (Zarocostas, 2020; Cuan-Baltazar et al., 2020), which defines that a series of false information penetrates into the life and public consciousness, while being "mixed" with information of high quality, proven, true, and valid. ICT tools are effective in communicating in crisis situations (Strzelecki \& Rizun, 2020; Springer et al., 2021; Kubiczek \& Hadasik, 2021; Hadasik \& Kubiczek, 2021; Kubiczek, 2021) because they are able to provide efficiently proven information. Furthermore, the 
availability and utilization of ICT tools contributes to the curtailment of uncertainty in crisis conditions (Koettl, 2017). Notwithstanding, the process of checking the source and credibility of the information held should always be present in order to minimize the phenomenon of disinformation adversely affecting the decisions made (Kubiczek \& Hadasik, 2021).

\section{THE PARTICIPATION OF ICT IN IMPROVING MARKET EFFICIENCY}

In the era of the information society, where access to the Internet is common, almost every industry of the market is undergoing the process of digitization. Enterprises use electronic communication instruments in sales between companies (B2B) as well as with the consumer (B2C), inter alia, through price communication of their goods and services. It is noted that companies adopting ICT and digitizing achieve a more substantial competitive advantage (Ong \& Ismail, 2008; Mihalic \& Buhalis, 2013; Qosasi et al., 2019), which translates into higher corporate profits (Fadun, 2013) and more favorable stock exchange quotations (in the circumstance of joint-stock companies; Okwu, 2015).

The current world in the era of widespread access to the Internet is significantly different from the one that existed more than 20 years ago, when access to a computer was rare, and the presence of smartphones and other digital mobile devices was unheard of. Purchases were made mainly in stationary stores (or occasionally over the phone), and promotions and occasions were communicated through TV, radio, or paper/newspaper advertisements. It is noted that the use of internet mechanisms in enterprises translates into higher rates of return on the activity performed (Włodarczyk, 2015). Marketing in the "pre-Internet" era was remarkably different from what it is today - due to the high costs of producing and distributing advertisements to traditional mass media (Kucharska, 2015). Currently, communication takes place mainly through the available electronic media, and traditional mass media play a lesser role now because in them messages are primarily targeted at "traditional" recipients or those not characterized by a sufficiently high level of "digital literacy" (Nasah et al., 2010). On the other hand, in the case of young people (especially from the Y and Z generation), communication via the Internet is something natural and essential due to the unquestionable convenience of sending information for people who are highly proficient in navigating in the digital environment (Pawlasová \& Klézl, 2017; Bieleń \& Kubiczek, 2020).

The use of the internet-oriented approach means that in a short time and at a low cost, consumers are able to collect a great deal of information about the product or service they are interested in. With the help of currently existing internet portals, which are price comparison websites, it is possible to check the price of an interesting product at various points of sale. Thanks to the possibility of comparing prices through broad access to information via the Internet, the consumer will choose an identical product at the lowest possible price without losing its quality. By effectively managing household finances in the form of an appropriate allocation of funds in the basket of goods, households can save funds in their budgets.

The Internet is also proving useful in the times of the current crisis, such as the coronavirus pandemic, through which transactions are made or contracts concluded remotely (also in the international space, which results from the definition of the Internet). The Internet enables fast, convenient and direct communication with users from all over the world in real time. In particular, during the COVID-19 pandemic, many service industries moved their activities to the Internet sphere (Wnukowski, 2020) because with the help of electronic communication and information tools it is possible to arrange meetings with employees or contractors, manage the circulation of information or documents, and make transactions and even enter into contracts. Electronic communication instruments are capable of immediately notifying citizens about crisis situations by means of alerts sent to mobile devices, and users of social networks can receive information about interesting information from social, business or financial life through personalized notifications.

\section{CONCLUSIONS}

The Internet is a technological innovation that has enabled fast, efficient and low-cost communication between stakeholders worldwide in real time. However, many people around the world still do not have access to the Internet, and the proportion of people who do not have sufficient skills to use the instruments of the digital world is correspondingly higher. As a result, there is a noticeable limitation in a transmission of information by electronic means to people who do not have a sufficiently high level of digital literacy.

ICT tools are currently used by the vast majority of households, private and public enterprises, as well as government bodies. Due to faster flow and access to information, the way of managing assets and savings has altered, as has been the case with the improvement of decision-making processes by all economic entities. Thanks to the better circulation of information and the possibility of verifying its truthfulness with the utilization of ICT instruments, an inappropriate investment decision is minimized. Moreover, better investment decisions are made and in less time.

Central banks take advantage of electronic communication mechanisms in order to conduct an effective, credible and transparent information policy. Improving communication processes with the use of Internet technologies directly affects a transmission speed of changes in interest rates. Due to this: the market reaction is instant, and stakeholders immediately make investments or adjustments in accordance with the information provided by the issuer of the announcements.

From the consumers' point of view, the dissemination of price data allows to maintain the constant usefulness of the basket of goods and minimize their price, which usually takes place to the mutual benefit of the entrepreneur and the 
consumer. The speed of reaching information and the possibility of its processing or further transmission increases the effeciency of enterprises, as well as simplifies decision-making processes for investors or households.

\section{LIMITATION AND STUDY FORWARD}

The limitation of this work is the mere theoretical exploration of the above-mentioned issues related to ICT applications. Extending the study with practical aspects, including empirical examination of the impact of using ICT tools on the quality of the company's performance, may be considered the right direction for further research.

\section{ACKNOWLEDGEMENTS}

Author would like to express an appreciation to Jakub Kubiczek for constructive and fruitful comments as well as his valuable support.

\section{CONFLICT OF INTEREST AND ETHICAL STANDARDS}

The author states that there was no conflict of interest in any area during the whole paper writing and publication process.

\section{REFERENCES}

1. Adamska, A., \& Dąbrowski, T. J. (2016). Do investors appreciate information about corporate social responsibility? Evidence from the Polish equity market. Engineering Economics, 27(4). https://doi.org/10.5755/j01.ee.27.4.13377

2. Altman, E. I., \& Rijken, H. A. (2004). How rating agencies achieve rating stability. Journal of Banking \& Finance, 28(11), 2679-2714. https://doi.org/10.1016/j.jbankfin.2004.06.006

3. Bañares, J. Á., \& Altmann, J. (2018). Economics behind ICT infrastructure management. Electronic Markets, 28(1), 7-9. https://doi.org/10.1007/s12525-018-0288-3

4. Bankole, F. O., Osei-Bryson, K.-M., \& Brown, I. (2015). The impact of information and communications technology infrastructure and complementary factors on intra-African trade. Information Technology for Development, 21(1), 12-28. https://doi.org/10.1080/02681102.2013.832128

5. Bieleń, M., \& Kubiczek, J. (2020). Response of the labor market to the needs and expectations of Generation Z. $e$ mentor, 4(86), 87-94. http://doi.org/10.15219/em86.1486

6. Chengalur-Smith, I. N., Ballou, D. P., \& Pazer, H. L. (1999). The impact of data quality information on decision making: an exploratory analysis. IEEE Transactions on Knowledge and Data Engineering, 11(6), 853864. https://doi.org/10.1109/69.824597

7. Cole, H., \& Cooley, T. (2014). Rating Agencies. National Bureau of Economic Research (Working Paper No. 19972). https://doi.org/10.3386/w19972

8. Crotts, J. (1999). Consumer Decision Making and Prepurchase Information Search. In Consumer Behavior in Travel and Tourism (1st ed., pp. 149-168). Routledge.

9. Cuan-Baltazar, J. Y., Muñoz-Perez, M. J., Robledo-Vega, C., Pérez-Zepeda, M. F., \& Soto-Vega, E. (2020). Misinformation of COVID-19 on the internet: Infodemiology study. JMIR Public Health and Surveillance, 6(2), e18444. https://doi.org/10.2196/18444

10. Czernich, N., Falck, O., Kretschmer, T., \& Woessmann, L. (2011). Broadband infrastructure and economic growth: Broadband infrastructure and economic growth. Economic Journal, 121(552), 505-532. https://doi.org/10.1111/j.1468-0297.2011.02420.x

11. De Bondt, W. F., \& Thaler, R. (1985). Does the stock market overreact?. The Journal of Finance, 40(3), 793805. https://doi.org/10.1111/j.1540-6261.1985.tb05004.x

12. Devine, D. G., \& Marion, B. W. (1979). The influence of consumer price information on retail pricing and consumer behavior. American Journal of Agricultural Economics, 61(2), 228-237.

13. Fadun, O. S. (2013). Information and communication technology (ICT) and insurance companies profitability in Nigeria. Journal of Accounting, Business and Management, 20(2), 1-13.

14. Falkowski, A., \& Tyszka, T. (2009). Psychologia zachowań konsumenckich. Gdańsk: Gdańskie Wydawnictwo Psychologiczne.

15. Grądalski, F., \& Guzikowska, P. (2015). Koordynacja Polityki Pieniężnej i Fiskalnej w Teorii i Praktyce. Redakcja naukowa Mateusz Kaleta Maria Laska Dorota Żuchowska, 11, 19-20.

16. Grinold, R. C., \& Kahn, R. N. (2000). The efficiency gains of long-short investing. Financial Analysts Journal, 56(6), 40-53. https://doi.org/10.2469/faj.v56.n6.2402

17. Hadasik, B., \& Kubiczek, J. (2021). On enhancing and automating the COVID-19 case reporting system in Poland. Humanities \& Social Sciences Reviews, 9(4), 209-213. https://doi.org/10.18510/hssr.2021.9429

18. Hazenberg, H., van den Hoven, J., Cunningham, S., Alfano, M., Asghari, H., Sullivan-Mumm, E., Ebrahimi Fard, A., \& Turcios Rodriguez, E. (2018). Micro-Targeting and ICT media in the Dutch Parliamentary system: Technological changes in Dutch Democracy. State Commission on the Parliamentary System. Delft Unniversity of Technology.

19. Kahneman, D., \& Tversky, A. (1979). Prospect Theory: An Analysis of Decision under Risk. Econometrica, 47(2), 263-292. https://doi.org/10.2307/1914185

20. Kahneman, D., Slovic, P., Tversky, A. (1982). Judgment under uncertainty: Heuristics and biases. Cambridge University Press. 
21. Kahneman, D., \& Tversky, A. (1984). Choices, values, and frames. American Psychologist, 39(4), 341-350. https://doi.org/10.1037/0003-066X.39.4.341

22. Kaźmierczak, A. (2000). Polityka pieniężna $w$ gospodarce rynkowej. Warszawa: Polskie Wydawnictwo Naukowe.

23. Koettl, C. (2017). Sensors everywhere: Using satellites and mobile phones to reduce information uncertainty in human rights crisis research. Genocide Studies and Prevention, 11(1), 36-54. https://doi.org/10.5038/19119933.11.1.1440

24. Kubiczek, J. (2020a). Polityka monetarna FED, EBC oraz NBP w obliczu pandemii SARS-CoV-2. In A. Borcuch, J. Kubiczek (Eds.), Ekonomia i finanse w XXI wieku. Wyzwania dla zglobalizowanego świata (pp. 125-138). Łódź-Kielce: Wydawnictwo Naukowe ArchaeGraph. http://doi.org/10.5281/zenodo.4697021

25. Kubiczek, J. (2020b). Corporate bond market in Poland-prospects for development. Journal of Risk and Financial Management, 13(12), 306. https://doi.org/10.3390/jrfm13120306

26. Kubiczek, J. (2021). Implementation of The Digital Green Certificate (COVID passport) as a key ICT project in the European Union - a scientific comment. Humanities \& Social Sciences Reviews, 9(4), 01-03. https://doi.org/10.18510/hssr.2021.941

27. Kubiczek, J., \& Bieleń, M. (2021). The level of socio-economic development of regions in Poland. Wiadomości Statystyczne. The Polish Statistician, 66(11), 27-47. https://doi.org/10.5604/01.3001.0015.5130

28. Kubiczek, J., \& Hadasik, B. (2021). Challenges in reporting the COVID-19 spread and its presentation to the society. Journal of Data and Information Quality, 13(4), 1-7. https://doi.org/10.1145/3470851

29. Kucharska, B. (2015). Wirtualizacja zachowań nabywczych jako przejaw innowacyjności konsumentów w handlu detalicznym. Marketing i Rynek, (10), 40-45.

30. Liberda, B., Tokarski, T., \& Kaczorowski, P. (2002). Wpływ stóp procentowych i stóp podatkowych na oszczędności i inwestycje. Gospodarka Narodowa, (1-2), 47-68.

31. Maynard, R. (2018). Does investing have to be complicated? In Wealth of Wisdom: The Top 50 Questions Wealthy Families Ask (pp. 107-113). John Wiley \& Sons, Ltd. https://doi.org/10.1002/9781119331568.ch16

32. Mihalic, T., \& Buhalis, D. (2013). ICT as a new competitive advantage factor-case of small transitional hotel sector. Economic and Business Review, 15(1), 33-56.

33. Nagy, R. A., \& Obenberger, R. W. (1994). Factors influencing individual investor behavior. Financial Analysts Journal, 50(4), 63-68. https://doi.org/10.2469/faj.v50.n4.63

34. Nasah, A., DaCosta, B., Kinsell, C., \& Seok, S. (2010). The digital literacy debate: an investigation of digital propensity and information and communication technology. Educational Technology Research and Development, 58(5), 531-555. https://doi.org/10.1007/s11423-010-9151-8

35. Ng, T. H., Lye, C. T., \& Lim, Y. S. (2013). Broadband penetration and economic growth in ASEAN countries: a generalized method of moments approach. Applied Economics Letters, 20(9), 857-862. https://doi.org/10.1080/13504851.2012.754538

36. Okwu, A. T. (2015). ICT adoption and financial markets: A study of the leading stock exchange markets in Africa. Journal of Accounting and Management, 5(2), 53-76.

37. Ong, J. W., \& Ismail, H. B. (2008). Sustainable competitive advantage through information technology competence: resource-based view on small and medium enterprises. Communications of the IBIMA, 1(7), 6270 .

38. Otuteye, E., \& Siddiquee, M. (2015). Overcoming cognitive biases: A heuristic for making value investing decisions. The Journal of Behavioral Finance, 16(2), 140-149. https://doi.org/10.1080/15427560.2015.1034859

39. Qosasi, A., Permana, E., Muftiadi, A., Purnomo, M., \& Maulina, E. (2019). Building SMEs’ competitive advantage and the organizational agility of apparel retailers in Indonesia: The role of ICT as an initial trigger. Gadjah Mada International Journal of Business, 21(1), 69-90.

40. Pawlasová, P., \& Klézl, V. (2017). Factors affecting generation Y customers' satisfaction with online groupbuying purchases in South Korea. Acta Universitatis Agriculturae et Silviculturae Mendelianae Brunensis, 65(6), 2045-2054. https://doi.org/10.11118/actaun201765062045

41. Petryka, P. (2021). Przegląd zastosowania antycyklicznego bufora kapitałowego w EOG w reakcji na wybuch pandemii wirusa SARS-CoV-2. Finanse i Prawo Finansowe, 4(32), 47-65. https://doi.org/10.18778/23916478.4.32.04

42. Raghunathan, S. (1999). Impact of information quality and decision-maker quality on decision quality: a theoretical model and simulation analysis. Decision Support Systems, 26(4), 275-286. https://doi.org/10.1016/s0167-9236(99)00060-3

43. Richardson, M. P., \& White, L. J. (2009). The rating agencies. In Restoring financial stability: How to repair a failed system (pp. 101-116), Wiley Finance.

44. Shahiduzzaman, M., \& Alam, K. (2014). The long-run impact of Information and Communication Technology on economic output: The case of Australia. Telecommunications Policy, 38(7), 623-633. https://doi.org/10.1016/j.telpol.2014.02.003

45. Shen, D., Zhang, W., Xiong, X., Li, X., \& Zhang, Y. (2016). Trading and non-trading period Internet information flow and intraday return volatility. Physica A: Statistical Mechanics and its Applications, 451, 519524. https://doi.org/10.1016/j.physa.2016.01.086 
46. Shirazi, F., Gholami, R., \& Añón Higón, D. (2009). The impact of information and communication technology (ICT), education and regulation on economic freedom in Islamic Middle Eastern countries. Information \& Management, 46(8), 426-433. https://doi.org/10.1016/j.im.2009.08.003

47. Skibińska-Fabrowska, I. (2015). Forward guidance jako instrument polityki pieniężnej-możliwości wykorzystania. Kwartalnik Kolegium Ekonomiczno-Społecznego „, Studia i Prace”, 23(3.1), 51-60.

48. Smyczek, S. (2000). Modele rynkowych zachowań konsumentów. Prace Naukowe/Akademia Ekonomiczna w Katowicach, 77-101.

49. Sowa, I. (1997). Wpływ informacji marketingowej na zachowania konsumenta. Zeszyt Naukowy/Akademia Ekonomiczna im. Karola Adamieckiego, (141), 73-103.

50. Springer, S., Zieger, M., \& Strzelecki, A. (2021). The rise of infodemiology and infoveillance during COVID19 crisis. One Health, 13(100288), 100288. https://doi.org/10.1016/j.onehlt.2021.100288

51. Strzelecki, A., Rizun, M. (2020). Infodemiological Study Using Google Trends on Coronavirus Epidemic in Wuhan, China. International Journal of Online and Biomedical Engineering, 16(04), 139-146. https://doi.org/10.3991/ijoe.v16i04.13531

52. Tversky, A., Kahneman, D. (1974). Judgment under Uncertainty: Heuristics and Biases. Science, 185(4157), 1124-1131. https://www.jstor.org/stable/1738360

53. Vu, K. M. (2013). Information and Communication Technology (ICT) and Singapore's economic growth. Information Economics and Policy, 25(4), 284-300. https://doi.org/10.1016/j.infoecopol.2013.08.002

54. White, L. J. (2013). Credit rating agencies: An overview. Annual Review of Financial Economics, 5(1), 93-122. https://doi.org/10.1146/annurev-financial-110112-120942

55. Włodarczyk, K. (2015). Wirtualizacja konsumpcji polskiego społeczeństwa. Prace Naukowe Uniwersytetu Ekonomicznego we Wroctawiu, (414), 237-249. https://doi.org/10.15611/pn.2015.414.18

56. Wnukowski D. (2020), Konsekwencje epidemii koronawirusa dla gospodarki UE. Bulletin of the Polish Institute of International Affairs, 45(1977). Retrieved from: https://pism.pl/upload/images/artykuly/4e306947c806-4ff6-873d-f99fe91ced02//1584623079453.pdf (accessed 18.12.2021).

57. Zaremba, A. (2015). Inflation, Business Cycles, and Commodity Investing in Financialized Markets. Business and Economics Research Journal, 6(1), 1-18.

58. Zarocostas, J. (2020). How to fight an infodemic. Lancet, 395(10225), 676. https://doi.org/10.1016/S01406736(20)30461-X

59. Zatwarnicka-Madura, B. (2009). Irracjonalność zachowań konsumenta. Studia i Prace Kolegium Zarządzania, 93, 9-21. 